\title{
The Biphasic Role of Cupper and Counteraction with Azospirillum brasilense Application on Growth, Metabolities, Osmotic Pressure and Mineral of Wheat Plant
}

\author{
Hamdia M. Abd El-Samad \\ Botany and Microbiology Department, Faculty of Science, Minia University, El-Minia, Egypt \\ Email: hamdia10@yahoo.com
}

How to cite this paper: Abd El-Samad, H.M. (2017) The Biphasic Role of Cupper and Counteraction with Azospirillum brasilense Application on Growth, Metabolities, Osmotic Pressure and Mineral of Wheat Plant. American Journal of Plant Sciences, 8, 1182-1195.

https://doi.org/10.4236/ajps.2017.85078

Received: March 2, 2017

Accepted: April 27, 2017

Published: April 30, 2017

Copyright $\odot 2017$ by author and Scientific Research Publishing Inc. This work is licensed under the Creative Commons Attribution International License (CC BY 4.0).

http://creativecommons.org/licenses/by/4.0/

\begin{abstract}
The interactive effect of different $\mathrm{Cu}^{++}$concentrations $(5 \mathrm{mM}, 10 \mathrm{mM}, 20 \mathrm{mM}$ and $25 \mathrm{mM}$ ) and treatments with biofertilizers Azospirillum brasilense on growth, metabolites, minerals and osmotic pressure of wheat plants was investigated. Shoots and roots of wheat plant were differentially response to $\mathrm{Cu}^{++}$treatments, while shoot organ response positively to this treatment, root response negatively. The positive effect of $\mathrm{Cu}^{++}$in shoot organ was concomitant with the increase in the production of fresh, dry matter, length and water content and this related with the accumulation of soluble sugar, soluble protein and mineral as a result of increasing osmotic pressure. On the other side, the negative effect of $\mathrm{Cu}^{++}$on root organ was concomitant with the decrease in production of fresh, dry matter, length and water content that related with the reduction in the accumulation of soluble sugar and mineral with the insignificant change in osmotic pressure. Azospirillum brasilense inoculation increased the accumulation of soluble sugar and soluble protein which reflected an increase in the production of fresh, dry matter and water content with increasing values of osmotic pressure of the tested plants under $\mathrm{Cu}^{++}$treatment. Finally, wheat plants response differentially to $\mathrm{Cu}^{++}$treatment according to its organ and Azospirillum brasilense treatment improved wheat plant efficiency to tolerate the effect of $\mathrm{Cu}^{++}$stress.
\end{abstract}

\section{Keywords \\ $\mathrm{Cu}^{++}$Treatment, Azospirillum brasilense, Wheat}

\section{Introduction}

$\mathrm{Cu}^{++}$is required within the plant cell, in at least six locations: cytoplasm, the en- 
doplasmic reticulum (ER), mitochondrial inner membrane, stroma chloroplast, apoplast and lumen thylakoid [1]. $\mathrm{Cu}^{+}$was contributed in many biochemical and physiological activities because it is able to exit in multiple oxidation states in vivo; cupper can exit as $\mathrm{Cu}^{++}$and $\mathrm{Cu}^{+}$; the cation $\mathrm{Cu}^{++}$is bound with nitrogen in histidine side chains, whereas $\mathrm{Cu}^{+}$prefers the interaction with the sculpture in cystein or methionine. $\mathrm{Cu}^{++}$was considered as the structural element in metall proteins, which involved in chloroplasts electron transport and mitochondria and in oxidative stress response. $\mathrm{Cu}^{+}$has the ability to bind small molecules such as $\mathrm{O}_{2}$ as ligands, thus, $\mathrm{Cu}$ acts as the cofactor of a large number of oxidase [2]. Soil $\mathrm{Cu}^{++}$defficiency or in excess amount can cause the undesirable effect in plant growth and survival by adversely affecting physiological activities in plants which later effect on agriculture and human healthy. Thus, for healthy growth of plant and survival, $\mathrm{Cu}^{++}$must be absorbed from soil, transported, distributed in different plant cells regulated carefully. Soil fertility is lowered periodically related to soil erosions, the diminished of nutrients, and increasing of toxic ions, water logging and undistributed nutrient compounds. Recently, using biofertilizers has a promising component of nutrient supply in agriculture. Biofertilizers useful for crops are Azospirillum, Azotobacter, P-solubilizing bacteria, blue green algae and mycorrhizae [3] [4]. Azospirillums species are among facultative endophytic diazotrophic group which found on the surface and interior of roots [5]. Azospirillum has been reported as plant growth promotion in field and nursery plants, resulting in significant effects in plants [6].

Romero et al. (2003) and Sangeeth et al. (2008) [7] [8] were studied Azospirillum spp inoculation effects of indigenous selectively isolated from various black pepper in enhancing growth as total dry weight and increasing nutrient uptake as nitrogen, phosphorus and potassium in treated plants.

Thus, this work was carried out to study the more important features concerning $\mathrm{Cu}^{++}$stimulant or toxicity and try to increase wheat plant tolerance by Azospirillum inoculation treatments on growth, metabolic constituents and osmotic pressure of wheat plants grown for 21 days.

\section{Materials and Methods}

\subsection{Experimental Sites and Cupper Treatments}

Grain of cv. Giza 168 was obtained from Beni Suief, Seds Center, Egypt, Agricultural pharmacies in bags, already a factory prepared for research. Wheat plant was considered as one of the most important crop plants in Egypt because of its contribution as main nutrient foods for people. From investigation was carried out by Hamdia and Shaddad (2016) showed that the salt tolerance $(0.0,20 \mathrm{mM}$, $50 \mathrm{mM}, 100 \mathrm{mM}, 150 \mathrm{mM}, 200 \mathrm{mM}$ and $300 \mathrm{mM} \mathrm{NaCl}$ levels) of the four wheat cultivars, during vegetative growth and crop yield stages ranked as the following: cv. Sakha $94>$ Gimiza11 > cv. Gimiza $10>$ cv. Giza 168. This means that cv. Sakha 94 was the superior and cv. Giza 168 was the interior. Select cv. Giza 168 because it was most salt sensitive. Wheat grains were surface sterilized by immersion in a mixture of ethanol $96 \%$ and $\mathrm{H}_{2} \mathrm{O}_{2}$ (1:1) for 3 minutes, followed by 
several washings with sterile distilled water. Wheat (cv. Giza 168) plants were grown in vermiculate for one week and then transplanted in plastic pots fill with clay soil without $\mathrm{Cu}^{++}$treatment (control) and under different $\mathrm{Cu}^{++}$concentration as $\mathrm{CuSO}_{4}$ salt, $5 \mathrm{mM}, 10 \mathrm{mM}, 20 \mathrm{mM}$ and $25 \mathrm{mM}$ were added to the soil in such a way that the soil solution acquired the assigned $\mathrm{Cu}^{++}$concentrations at field capacity in growth chamber (Forma Scientific, Marietta, Ohio, U.S.A.) at $30 / 25^{\circ} \mathrm{C}, 12 \mathrm{~h}$ day/night cycles and $60 \mathrm{Wm}^{2}$ ). The clay soil comprise four components minerals and soil organic matter make up the solid fraction, whereas air and water comprise the pore space fraction. A typical agricultural soil is usually around 50\% solid particles and 50\% pores (Adapted from Brady and Weil, 2002). Soil particle of clay is $<0.002$ invisible to naked eye. Considerations of working in controlled environments were followed by Tibbitts \& Langhans (1993) [9].

\subsection{Cupper Treatments with Azospirillum Inoculation}

Treatments of plants with different concentration began when seedlings transplanted in the plastic pot. The previous treatment group was repeated for Azospirillum brailense inoculation, inoculum was prepared by El-Komy (1992) [10] at bacteriology laboratory in Minia University, Faculty of Science, Botany and Microbiology Department.

\subsection{Laboratory Analysis for Metabolities}

A week after the plants was used for analysis after 21-days. Dry matter was determined after drying plants in an aerated oven at $70^{\circ} \mathrm{C}$ to constant mass. Soluble sugar was determined by the anthrone-sulfuric acids method [11]. Soluble protein contents were measured according to Lowry et al. (1951) [12]. The osmotic pressure of tissue sap was measured by advanced wide-range Osmometer 3W2. $\mathrm{Na}^{+}$and $\mathrm{K}^{+}$were determined Flamphotometeric by Williams and Twin (1960) [13]. $\mathrm{Ca}^{++}$and $\mathrm{Mg}^{++}$were determined by Schwarzenbach and Biedermann (1948) [14].

\section{Statistical Analysis}

The experimental data were subjected to the one way analysis of variances (ANOVA test) using the SPSS version 11.0 to quantify and evaluate the source of variation and the means were separated by the least significant differences, L.S.D. at $\mathrm{P}$ level of $0.05 \%$ [15]. The percentage presented in the following tables was calculated by the data of fresh, dry matter, water content, length, soluble sugar, soluble protein, minerals and osmotic pressure of shoot and root at reference control plants, with different $\mathrm{Cu}^{++}$concentrations $5 \mathrm{mM}, 10 \mathrm{mM}, 20 \mathrm{mM}$ and $25 \mathrm{mM}$ and with $\mathrm{Cu}^{++}$concentrations plus Azospirllum inoculation of wheat cv. Giza 168. The data was compared by plants grow at control (untreated), the other different $\mathrm{Cu}^{++}$concentration and with $\mathrm{Cu}^{++}$under Azospirillum inoculation. The fresh, dry matter, length and water content were determined as $\mathrm{g}$ plant $^{-1}$, chemical constituents (soluble sugar, soluble protein and mineral con- 
tent) were determined as $\mathrm{mg} \cdot \mathrm{g}^{-1} \mathrm{~d} . \mathrm{m}$. Osmotic pressure was determined as ( $\mathrm{m}$ Osmo/ $\mathrm{kg} \mathrm{H}_{2} \mathrm{O}$ ).

\section{Results}

The date in Table 1 reveals that fresh and dry matter of shoot and root response differentially to different $\mathrm{Cu}^{++}$concentrations treatments. The low $\mathrm{Cu}^{++}$concentration $5 \mathrm{mM}$ significantly increase the production of fresh and dry matter of both shoot and root of wheat plants. The percent of increase at that level was $97.1 \%, 65 \%, 23.5 \%$ and $16.7 \%$ of fresh and dry matter of shoot and root, respectively. The moderate and high in $\mathrm{Cu}^{++}$concentrations (from $10 \mathrm{mM}$ to $25 \mathrm{mM}$ ) were significantly increasing the fresh and dry matter of shoot while significantly decreases these parameters in root organ compared with uncupper plant treatment. The percent of increase in fresh and dry matter in shoot and root at 25 $\mathrm{mM} \mathrm{Cu}{ }^{++}$concentration was $32.7 \%$ and $25 \%$, while the percent of reduction in root was $20 \%$ and $46.7 \%$ as compared with control plants.

The length of shoot and root was markedly increased with increasing $\mathrm{Cu}^{++}$ concentration up to $5 \mathrm{mM}$, above which a reduction was detected until reach a low levels at $25 \mathrm{mM} \mathrm{Cu}^{++}$(Table 2). The percent of reduction at that level of $\mathrm{Cu}^{++}$was $18.2 \%$ and $21.9 \%$ for shoot and root of wheat plants. Water content significantly increases with increasing $\mathrm{Cu}^{++}$concentration in both shoot and root; the high values were produced at $5 \mathrm{mM}$ for both organs (Table 2). This activation was more observed at low and moderate level of $\mathrm{Cu}^{++}$treatment. Soluble sugar was significantly increased at $5 \mathrm{mM} \mathrm{Cu}^{++}$concentration in shoot, after that, it become more or less unchanged compared with control plant (Table 3 ). While, $\mathrm{Cu}^{++}$treatment significantly decreased this content in root

Table 1. The effect of different $\mathrm{Cu}^{++}$concentrations and Azospirillum inoculation on fresh and dry matter g plant ${ }^{-1}$ in shoot and root of wheat plants grown for 21-days.

\begin{tabular}{ccccccccc}
\hline Treat. & \multicolumn{3}{c}{ Shoot } & & \multicolumn{3}{c}{ Root } \\
\hline mM & $\begin{array}{c}\text { F. m. } \\
\text { g.plant }\end{array}$ & $\%$ & $\begin{array}{c}\text { D. m. } \\
\text { g.plant }{ }^{-1}\end{array}$ & $\%$ & $\begin{array}{c}\text { F. m. } \\
\text { g.plant }\end{array}$ & $\%$ & $\begin{array}{c}\text { D. m. } \\
\text { g.plant }\end{array}$ & $\%$ \\
\hline Control & 0.104 & 100 & 0.02 & 100 & 0.051 & 100 & 0.03 & 100 \\
$5 \mathrm{mM}$ & $0.205^{* *}$ & 197.1 & $0.033^{* *}$ & 165 & $0.063^{* *}$ & 123.5 & $0.035^{* *}$ & 116.7 \\
$10 \mathrm{mM}$ & 0.155 & 149.0 & $0.027^{* *}$ & 135 & $0.039^{* *}$ & 76.4 & $0.015^{* *}$ & 50.0 \\
$20 \mathrm{mM}$ & $0.194^{*}$ & 186.5 & $0.028^{* *}$ & 140 & 0.042 & 82.4 & $0.016^{* *}$ & 53.3 \\
$25 \mathrm{mM}$ & 0.138 & 132.7 & $0.025^{* *}$ & 125 & 0.041 & 80 & $0.016^{* *}$ & 53.3 \\
Cont. $+A z$. & $0.227^{* *}$ & 218.3 & $0.039^{* *}$ & 195.0 & 0.057 & 111.8 & $0.035^{* *}$ & 116.7 \\
$5 \mathrm{mM}+A z$. & $0.262^{* *}$ & 251.9 & $0.035^{* *}$ & 175.0 & $0.064^{* *}$ & 125.5 & $0.028^{*}$ & 93.3 \\
$10 \mathrm{mM}+A z$. & $0.215^{* *}$ & 206.8 & $0.034^{* *}$ & 170.0 & $0.064^{* *}$ & 125.5 & $0.028^{*}$ & 93.3 \\
$20 \mathrm{mM}+A z$. & 0.174 & 163.5 & $0.029^{* *}$ & 145.0 & 0.052 & 101.9 & $0.023^{* *}$ & 76.8 \\
$25 \mathrm{mM}+A z$. & 0.156 & 150.0 & $0.029^{* *}$ & 145.0 & 0.055 & 107.8 & $0.024^{* *}$ & 80.0 \\
L. S. D. 5\% & 0.1 & & 0.003 & & 0.01 & & 0.002 & \\
\hline
\end{tabular}

${ }^{*}$ Highly significant $>0.05$. 
Table 2. The effect of different $\mathrm{Cu}^{++}$concentrations and Azospirillum inoculation in Length $(\mathrm{Cm})$, water content $\left(\mathrm{g} \cdot\right.$ plant $\left.^{-1}\right)$ of shoot and root of wheat plants grown for 21 days.

\begin{tabular}{|c|c|c|c|c|c|c|c|c|}
\hline \multirow{2}{*}{$\begin{array}{c}\text { Treatments } \\
\mathrm{mM}\end{array}$} & \multicolumn{4}{|c|}{ Length $(\mathrm{Cm})$} & \multicolumn{4}{|c|}{ Water content (g.plant ${ }^{-1}$ ) } \\
\hline & Shoot & $\%$ & Root & $\%$ & Shoot & $\%$ & Root & $\%$ \\
\hline Control & 22 & 100 & 7.3 & 100 & 0.084 & 100 & 0.021 & 100 \\
\hline $5 \mathrm{mM}$ & $24.3^{\star *}$ & 110.5 & $8.2^{*}$ & 112.3 & $0.172^{\star *}$ & 204.8 & 0.028 & 133.3 \\
\hline $10 \mathrm{mM}$ & $20.3^{* *}$ & 92.3 & 7.7 & 105 & 0.128 & 152.3 & 0.024 & 114.3 \\
\hline $20 \mathrm{mM}$ & $20^{* *}$ & 90.9 & $6.2^{\star *}$ & 84.9 & $0.166^{* *}$ & 197.6 & 0.026 & 123.8 \\
\hline $25 \mathrm{~mm}$ & $18^{\star *}$ & 81.8 & $5.7^{\star *}$ & 78.1 & 0.113 & 134.5 & 0.025 & 119.0 \\
\hline Control + Az. & 19.5 & 88.6 & 8.0 & 109.6 & $0.188^{* *}$ & 223.8 & 0.022 & 104.8 \\
\hline $5 \mathrm{mM}+A z$ & $26.2^{\star *}$ & 119.0 & 8.0 & 109.6 & $0.227^{\star *}$ & 270.2 & $0.036^{\star *}$ & 174.4 \\
\hline $10 \mathrm{mM}+A z$ & $21^{\star \star}$ & 95.5 & 8.0 & 109.6 & $0.181^{* *}$ & 215.5 & $0.036^{* *}$ & 171.4 \\
\hline $20 \mathrm{mM}+A z$ & $21^{\star \star}$ & 95.5 & 7.5 & 102.7 & $0.141^{\star \star}$ & 167.8 & $0.029^{\star *}$ & 138.1 \\
\hline $25 \mathrm{mM}+A z$ & $19^{\star *}$ & 86.4 & 6.5 & 89.0 & 0.127 & 151.2 & $0.031^{*}$ & 147.6 \\
\hline L. S. D. $5 \%$ & 0.6 & & 0.9 & & 0.05 & & 0.01 & \\
\hline
\end{tabular}

${ }^{* *}$ Highly significant $>0.05$.

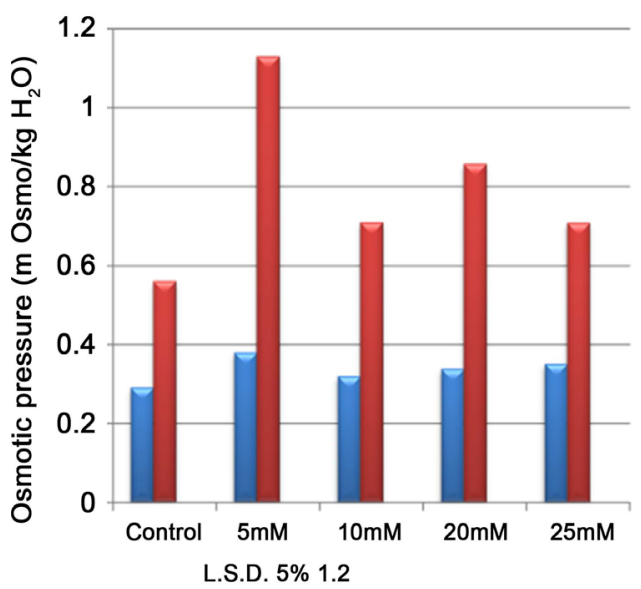

(a)
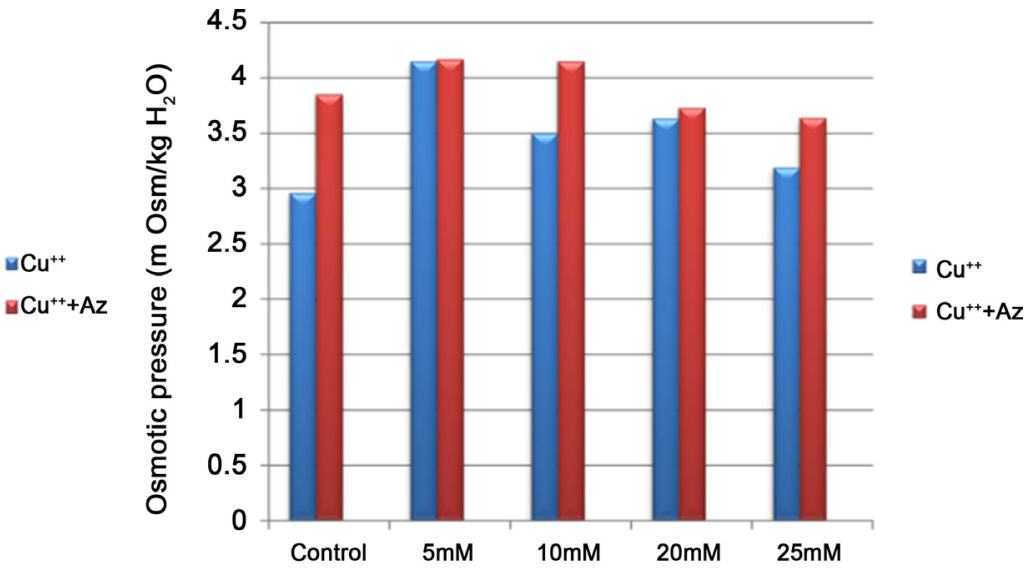

(b)

Figure 1. Counteraction of $\mathrm{Cu}^{++}$and treatment with Azospirillum brasilense on osmotic pressure (m Osmo/kg $\left.\mathrm{H}_{2} \mathrm{O}\right)$ of shoot (a) and root (b) of wheat plants grown for 21 days.

especially at higher $\mathrm{Cu}^{++}$concentration. Soluble protein was markedly accumulated in both shoot and root of wheat plant (Table 3). This accumulation was higher in shoot than in root organ and at $5 \mathrm{mM} \mathrm{Cu}^{++}$concentration in case of root. Osmotic pressure of wheat plants was markedly increased with increasing $\mathrm{Cu}^{++}$concentration in shoot and root (Figure 1(a), Figure 1(b)). This activation effects was more in root than in shoot organ of wheat plant. It is worthy to note that osmotic pressure (OP) represent a higher value at $5 \mathrm{mM} \mathrm{Cu}^{++}$concentration in shoot and root organ compared with untreated plants. This runs parallel with fresh, dry matter, length and water content. Mineral content of wheat plants showed a variable response to $\mathrm{Cu}^{++}$treatments. Sodium content was tended to 
increase in shoot and significantly accumulated in root with increasing $\mathrm{Cu}^{++}$ treatment (Figure 2(a), Figure 2(b)). This accumulation was pronounced at 25 $\mathrm{mM} \mathrm{Cu}{ }^{++}$concentration, the percent of increase was $266.6 \%$ and $233.3 \%$ of shoot and root respectively compared with untreated plants. $\mathrm{K}^{+}$in content was markedly increased in both shoot and root with increasing $\mathrm{Cu}^{++}$treatment, it decreased in root as compared with control plants (Figure 3(a), Figure 3(b)). It is worthy to note that the high value in $\mathrm{K}^{+}$accumulation in shoot was detected at 5 $\mathrm{mM}$ and $10 \mathrm{mM} \mathrm{Cu}^{++}$concentration. $\mathrm{Ca}^{++}$content was significantly increased at $5 \mathrm{mM} \mathrm{Cu}^{++}$concentration in shoot while at $10 \mathrm{mM} \mathrm{Cu}^{++}$produced the same value of control, above that a reduction was recorded (Figure 4(a), Figure 4(b)). In root

Table 3. The effect of different $\mathrm{Cu}$ concentrations and Azospirillum brasilense inoculation on soluble sugar $\left(\mathrm{mg} \cdot \mathrm{g}^{-1} \mathrm{~d}\right.$. m.) and soluble protein $\left(\mathrm{mg} \cdot \mathrm{g}^{-1} \mathrm{~d} . \mathrm{m}\right.$.) in shoot and root of wheat plants grown for 21-days.

\begin{tabular}{|c|c|c|c|c|c|c|c|c|}
\hline & \multicolumn{4}{|c|}{ Soluble sugar } & \multicolumn{4}{|c|}{ Soluble protein } \\
\hline & Shoot & $\%$ & Root & $\%$ & Shoot & $\%$ & Root & $\%$ \\
\hline Control & 32.1 & 100 & 63.3 & 100 & 32.7 & 100 & 34.4 & 100 \\
\hline $5 \mathrm{mM}$ & $45.1^{\star *}$ & 169.5 & $56.3^{* *}$ & 88.9 & 31.5 & 96.3 & $43.8^{\star *}$ & 127.7 \\
\hline $10 \mathrm{mM}$ & $33.5^{\star *}$ & 104.4 & $54.9^{* *}$ & 86.8 & $34.8^{\star *}$ & 106.4 & $31.9^{* *}$ & 92.7 \\
\hline $20 \mathrm{mM}$ & $30.4^{\star *}$ & 91.7 & $48.3^{\star * *}$ & 76.3 & $43.8^{\star *}$ & 133.9 & $35.8^{\star *}$ & 104.1 \\
\hline $25 \mathrm{~mm}$ & $33.4^{\star *}$ & 104.0 & $33.5^{\star *}$ & 52.9 & $41.9^{* *}$ & 128.1 & $36.1^{\star *}$ & 104.9 \\
\hline Control $+A z$. & $53.3^{\star *}$ & 166.0 & $150.9^{* *}$ & 238.4 & 32.4 & 99.1 & $30.2^{\star *}$ & 87.8 \\
\hline $5 \mathrm{mM}+A z$ & $46.3^{\star *}$ & 144.2 & $71.9^{\star *}$ & 113.6 & $34.3^{\star *}$ & 104.9 & 33.9 & 98.5 \\
\hline $10 \mathrm{mM}+A z$ & $47.7^{\star \star}$ & 148.6 & $98.6^{\star *}$ & 155.8 & $40.1^{\star *}$ & 122.6 & $38.9^{\star *}$ & 113.1 \\
\hline $20 \mathrm{mM}+A z$ & $35.0^{\star *}$ & 109.0 & $79.9^{\star *}$ & 123.2 & $43.7^{\star *}$ & 133.6 & $41.9^{* *}$ & 133.4 \\
\hline $25 \mathrm{mM}+A z$ & $36.9^{* *}$ & 114.9 & $45.4^{\star \star}$ & 71.7 & $51.4^{\star *}$ & 157.2 & $43.2^{\star *}$ & 125.6 \\
\hline L. S. D. $5 \%$ & 1.1 & & 1.2 & & 1.3 & & 0.8 & \\
\hline
\end{tabular}

${ }^{* *}$ Highly significant $>0.05$.

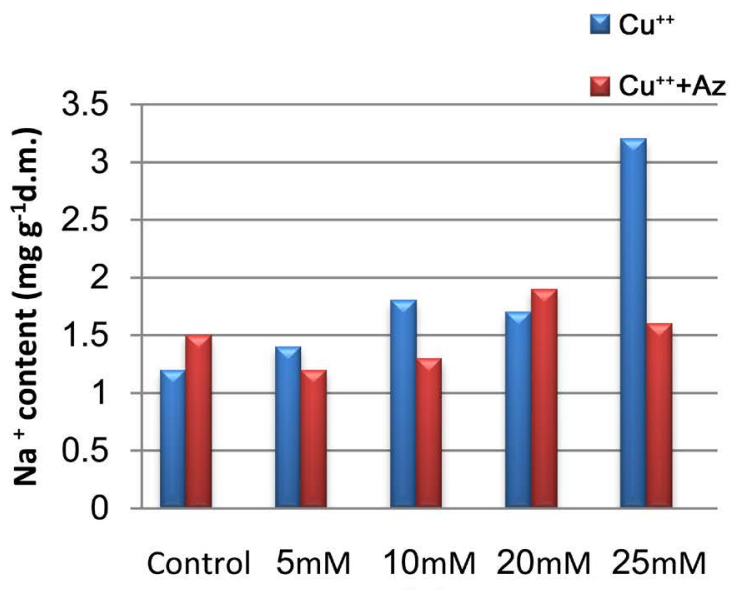

(a)

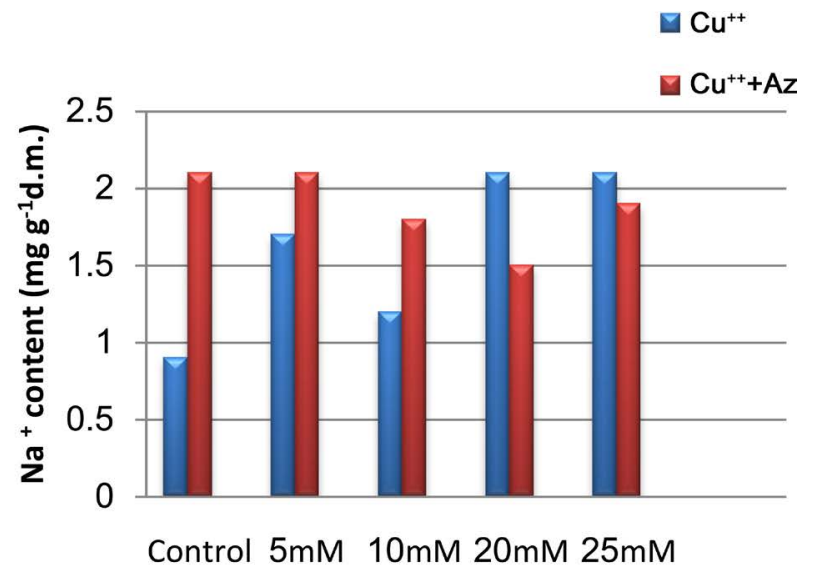

(b)

Figure 2. Effect of $\mathrm{Cu}^{++}$treatment with $A z$. inoculation on $\mathrm{Na}^{+}$content (mg.g ${ }^{-1} \mathrm{~d} . \mathrm{m}$.) in shoot (a) and root (b) wheat plants grown for 21 days. (a) L.S.D. 5\% 0.011; (b) L.S.D. 5\% 0.013. 


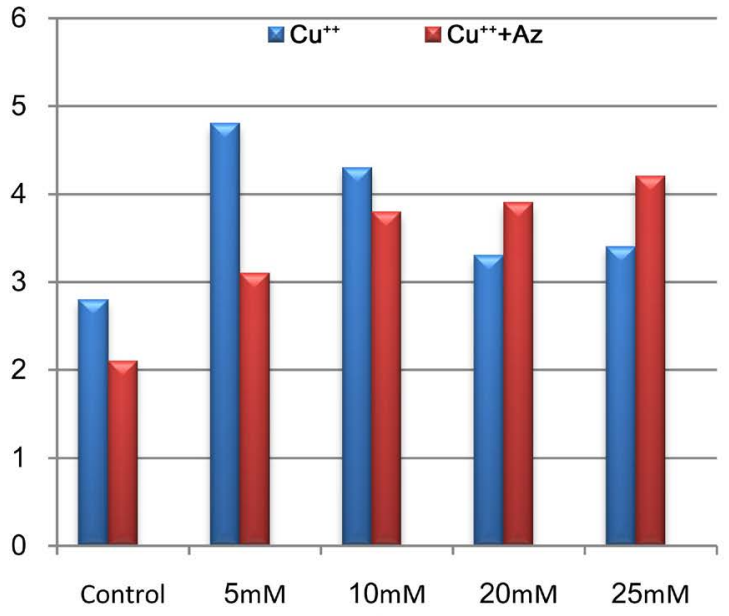

(a)

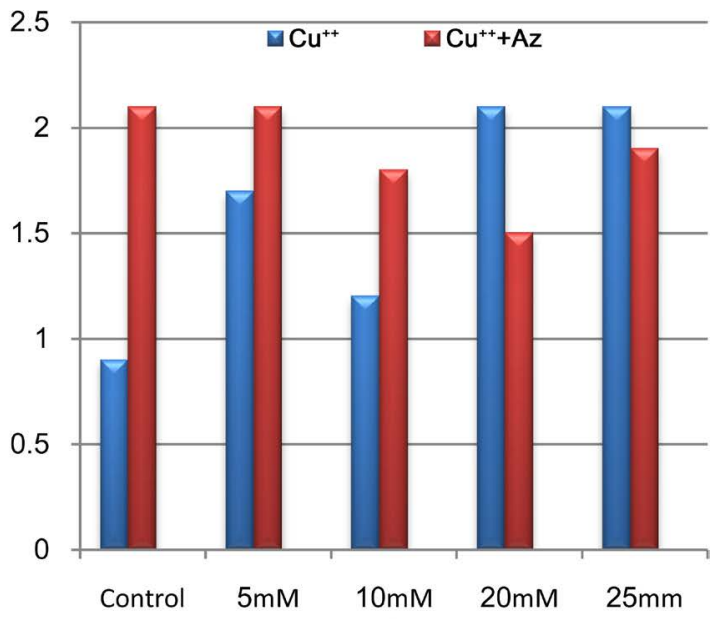

(b)

Figure 3. Effect of $\mathrm{Cu}^{++}$treatment with $A z$. inoculation on $\mathrm{K}^{+}$content (mg.g ${ }^{-1} \mathrm{~d} . \mathrm{m}$.) in shoot (a) and root (b) of wheat plants grown for 21 days. (a) L.S.D. $5 \%$ 0.014; (b) L.S.D. $5 \% 0.015$.

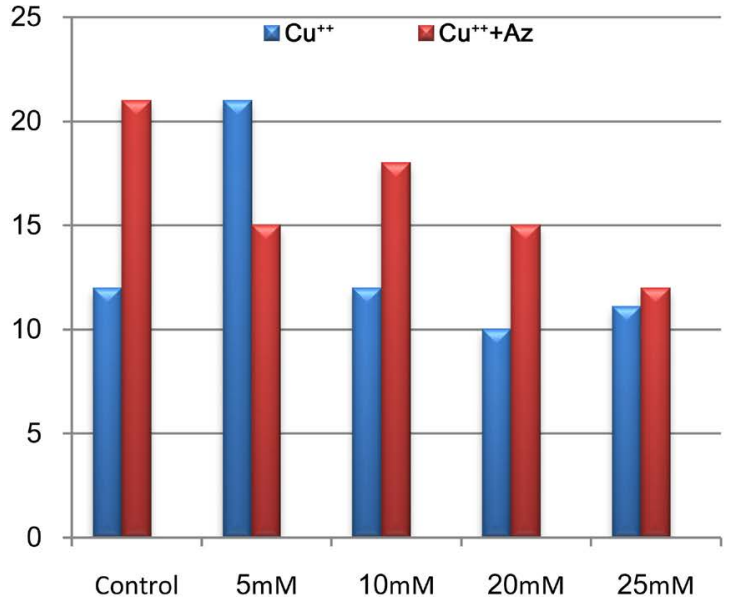

(a)

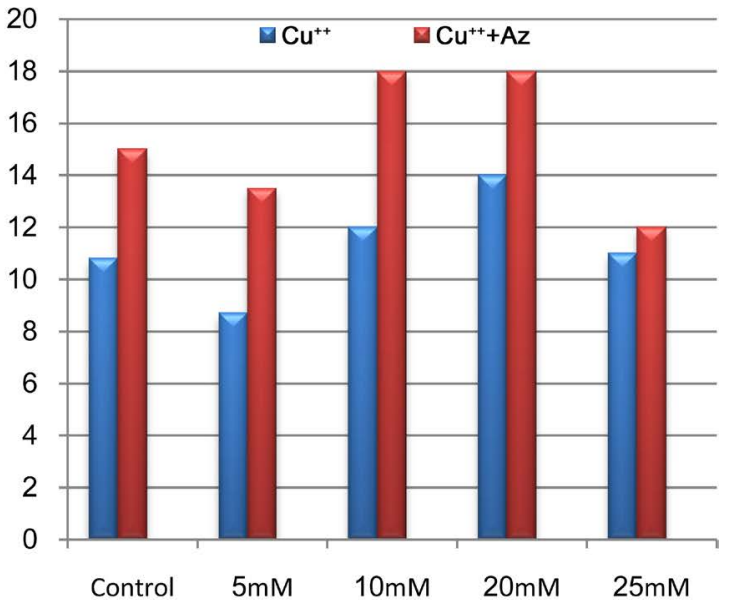

(b)

Figure 4. Effect of $\mathrm{Cu}^{++}$treatment with $A z$. inoculation on $\mathrm{Ca}^{++}$content (mg.g ${ }^{-1}$ d.m.) in shoot (a) and root (b) of wheat plants grown for 21 days. (a) L.S.D. 5\% 0.014; (b) L.S.D. $5 \% 0.015$.

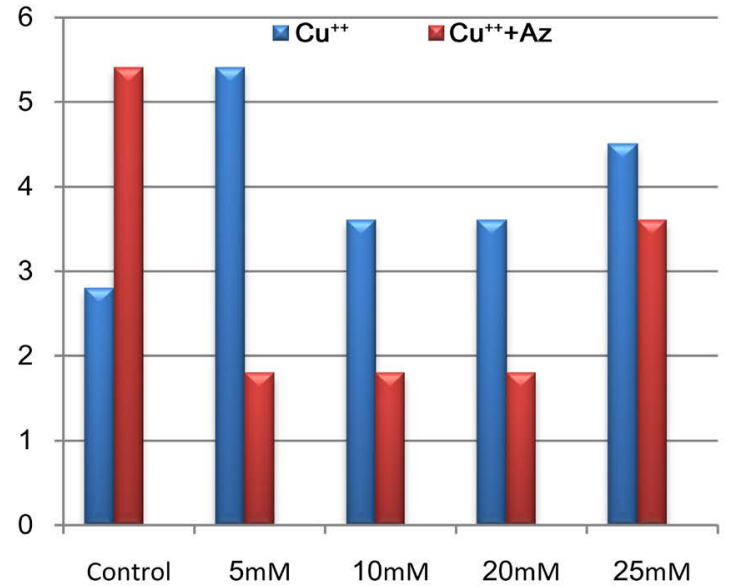

(a)

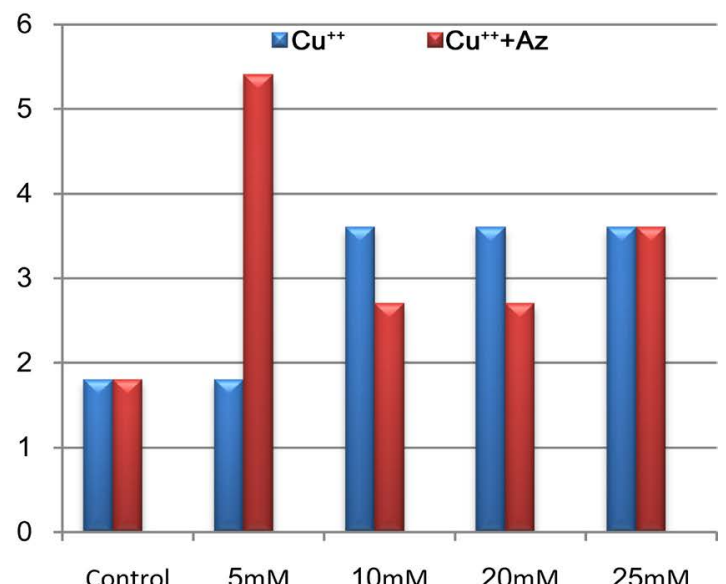

(b)

Figure 5. Effect of $\mathrm{Cu}^{++}$treatment with $A z$. inoculation on $\mathrm{Mg}^{++}$content (mg.g ${ }^{-1} \mathrm{~d} . \mathrm{m}$.) in shoot (a) and root (b) of wheat plants grown for 21 days. (a) L.S.D. 5\% 0.014; (b) L.S.D. $5 \% 0.015$. 
$\mathrm{Ca}^{++}$was significantly increased with elevated $\mathrm{Cu}^{++}$application. Also, Increasing $\mathrm{Cu}^{++}$concentration elevated $\mathrm{Mg}^{++}$accumulation in both shoot and root, the high values was observed at $5 \mathrm{mM} \mathrm{Cu}^{++}$level in shoot while in root the high value was recorded at $25 \mathrm{mM} \mathrm{Cu}^{++}$compared with uncupper treatment (Figure 5(a), Figure 5(b)). Azospirillum inoculation significantly enhanced the production of fresh and dry matter in shoot and root of wheat plants when compared with control plant (Table 1). This activation was more prominent at low $\mathrm{Cu}^{++}$concentrations ( $5 \mathrm{mM}$ and $10 \mathrm{mM}$ ). The percent of increase in fresh and dry matter of shoot at $5 \mathrm{mM} \mathrm{Cu}^{++}$was $151.9 \%$ and $75 \%$ for shoot and $25.5 \%$ for root fresh matter respectively. The percent of increase at $25 \mathrm{mM}$ was $50 \%$ and $45 \%$ in fresh and dry matter of shoot, while in root no significant effect was observed. Azospirillum application stimulates the length in shoot and root of wheat plant as compared with both untreated plant and the corresponding $\mathrm{Cu}^{++}$concentration (Table 2). Also, water content of shoot and root was progressively increased with increasing $\mathrm{Cu}^{++}$concentration. This increase was reaching 2 -folds especially at lower and moderate $(5 \mathrm{mM}$ and $10 \mathrm{mM}) \mathrm{Cu}^{++}$treatment and in shoot than in root organ (Table 2). The percent of activation in water content at $5 \mathrm{mM} \mathrm{Cu}^{++}$ concentration was $170.2 \%$ and $71.4 \%$ of shoot and root at $5 \mathrm{mM} \mathrm{Cu}^{++}$level and 151.5 and 71.4 at $10 \mathrm{mM} \mathrm{Cu}^{++}$level over the control value $100 \%$. Azospirillum application significantly elevates the accumulation of soluble sugar and soluble protein in both shoot and root compared with control plants (Table 3). This elevation was prominent at lower and moderate $\mathrm{Cu}^{++}$concentration in soluble sugar content and in soluble protein at the higher $\mathrm{Cu}^{++}$concentration in both shoot and root of wheat plant. The percent of increase in case of soluble sugar at $10 \mathrm{mM}$ with Azospirillum inoculation was $48.6 \%$ and $55.8 \%$ over the control value $100 \%$ in shoot and root, in case of soluble protein at $25 \mathrm{mM}$ with Azospirillum treatment this percent was $57.2 \%$ and $33.4 \%$ over the control plant. Azospirillum application significantly enhanced the values of OP in shoot with increasing $\mathrm{Cu}^{++}$concentration. The percent of activation was reached 3 -folds at 5 $\mathrm{mM} \mathrm{Cu}{ }^{++}$concentration than the control or the corresponding $\mathrm{Cu}^{++}$concentration plant. In root, there is a slight increase of $\mathrm{OP}$ with increasing $\mathrm{Cu}^{++}$concentration, the high values was recorded at $5 \mathrm{mM} \mathrm{Cu}^{++}$concentration. Azospirillum inoculation significantly decreases the $\mathrm{Na}^{+}$accumulation with increasing $\mathrm{Cu}^{++}$ concentration in shoot and in root at higher $\mathrm{Cu}^{++}$value of wheat plant (Figure 2(a) \& Figure 2(b)). Potassium and calcium content increased with the elevating $\mathrm{Cu}^{++}$concentration in shoot and root of wheat plants (Figure 3(a), Figure 3(b) \& Figure 4(a), Figure 4(b)). $\mathrm{Mg}^{++}$remain unchanged in shoot and root with Azspirillum treatments at all levels of $\mathrm{Cu}^{++}$concentration, at $5 \mathrm{mM}$ in root a high value was produced than the other $\mathrm{Cu}^{++}$concentration (Figure 5(a) \& Figure 5(b)). Data in Table 4 showed that relative nutrient content increased with increasing $\mathrm{Cu}^{++}$content in shoot and root until reached higher values at $25 \mathrm{mM}$ $\mathrm{Cu}^{++}$concentration with Azospirillum application, except of this trend relative nutrient content decreased in case of root $\mathrm{Mg}^{++}$. Lai et al. (2008) [16] have proposed a new type of data analysis which considers both biomass and nutrient 
Table 4. The effect of different $\mathrm{Cu}^{++}$concentrations and Azospirillum inoculation on relative nutrient accumulation of shoot and root of wheat plants.

\begin{tabular}{ccccccccc}
\hline Treat. mM & Sh. Na & Sh. $\mathrm{K}^{+}$ & Sh. $\mathrm{Ca}^{++}$ & Sh. $\mathrm{Mg}^{++}$ & Ro. Na & Ro. $\mathrm{K}^{+}$ & Ro. $\mathrm{Ca}^{++}$ & Ro. $\mathrm{Mg}^{++}$ \\
\hline Cont. & 0.925 & 0.56 & 0.426 & 0.284 & 1.66 & 0.162 & 0.339 & 2.66 \\
$5 \mathrm{mM}$ & 0.931 & 0.837 & 1.15 & 0.230 & 1.67 & 0.164 & 0.670 & 4.6 \\
$10 \mathrm{mM}$ & 2.76 & 1.74 & 1.07 & 0.229 & 1.88 & 0.453 & 0.770 & 0.768 \\
$20 \mathrm{mM}$ & 5.51 & 2.72 & 2.9 & 0.580 & 1.99 & 1.95 & 1.59 & 0.78 \\
$25 \mathrm{mM}$ & 5.6 & 4.55 & 11.5 & 3.47 & 3.71 & 2.65 & 4.7 & 0.78 \\
\hline
\end{tabular}

content of plants. This new type of analysis has shown the importance of the mineral content of plant. The relative nutrient accumulation rate can be calculated by the following relationship:

$\frac{\text { Biomass in inoculated }}{\text { Biomass in non-inoculated }} \times \frac{\text { Mineral content in inoculated }}{\text { Mineral content in non-inoculated }} \times 100$

Our data showed that relative nutrient content increased with increasing $\mathrm{Cu}^{++}$ content until reached a higher values at $25 \mathrm{mM} \mathrm{Cu}^{++}$concentration with Azospirillum application. Inoculation facilitated in the plant yield and mineral content by some selected mechanisms or by a cascade of mechanisms operating simultaneously under suitable conditions.

\section{Discussion}

The present work was conducting the biphasic role of different $\mathrm{Cu}^{++}$concentrations ( $5 \mathrm{mM}, 10 \mathrm{mM}, 15 \mathrm{mM}$ and $25 \mathrm{mM}$ ) and treatments with biofertilizers Azospirillum brasilense on growth, metabolites, osmotic pressure and mineral content of wheat plants. Shoot and root of wheat plant were differentially response to $\mathrm{Cu}^{++}$treatments, while shoot organ response positively to this treatment, root response negatively. $\mathrm{Cu}^{++}$acts as activator metal in shoot organ while acts as inhibitory metal in root organ. This activation effect in shoot organ was concomitant with the increase in the production of fresh and dry matter which was related with the accumulation of soluble sugar and soluble protein that share in increasing osmotic pressure of the cell sap. This accumulation can be functioning in the increase of water uptake of wheat plants which support the view that $\mathrm{Cu}^{++}$successes in the utilization of carbohydrate and $\mathrm{N}$-metabolism and finally reflected on the increase of growth parameters [17] [18]. Thus, plants required $\mathrm{Cu}^{++}$for normal growth and development, when it was not enough specific symptoms to develop on young leaves and reproductive organs [19]. However, the negative response of root to $\mathrm{Cu}^{++}$treatment was related with the inhibition of fresh and dry matter which produced as the result of the decrease in the accumulation of soluble sugar and soluble protein at lower $\mathrm{Cu}^{++}$concentration and the increase in OP. This means that OP increases the efficiency of root organ to survive under the inhibitory effect of $\mathrm{Cu}^{++}$addition. It is worthy to mention Yuan et al. (2013) [20] observed that heavy metal copper $\left(\mathrm{Cu}^{++}\right)$is an essential microelement required for normal plant growth and development, but it in- 
hibits primary root growth when in excess. On the other hand, redox properties that make $\mathrm{Cu}^{++}$essential element also contributed to its inherent toxicity in shoot of wheat plant. Redox cycling between $\mathrm{Cu}^{++}$and $\mathrm{Cu}^{+}$can catalyze the production of highly toxic hydroxyl radicals, with subsequent damage to cells at level of lipids, membranes, nucleic acids, proteins and other biomolecules [21]. The mechanism underlying how excess $\mathrm{Cu}^{++}$functions in this process remains to be further elucidated. At this position from our result, $\mathrm{Cu}^{++}$acts as chemical fertilizers for shoot wheat plants or the tested soil suffering from $\mathrm{Cu}^{++}$deficiency while caused an inhibition effect in root organ. Wheat plant can tolerated the addition of $\mathrm{Cu}^{++}$from $10 \mathrm{mM}$ to $20 \mathrm{mM}$. This tolerance was related with the increase in water uptake of shoot and roots which concomitant with the increase of mineral content in both wheat organs as $\mathrm{Na}^{+}, \mathrm{K}^{+}, \mathrm{Mg}^{++}$and root $\mathrm{Ca}^{++}$. However, a significant reduction was observed at $25 \mathrm{mM} \mathrm{Cu}^{++}$concentration in shoot and root of wheat plant, this reduction was more in root than in shoot. Actually, lower level of $\mathrm{Cu}^{++}$treatment $5 \mathrm{mM}$, induced an increase in soluble sugar, shoot $\mathrm{K}^{+}, \mathrm{Ca}^{++}$and $\mathrm{Mg}^{+}$in the cell sap, this resulting an increasing effect in OP which finally activated more water uptake. This also in turn was resulting an increase in the production of growth parameters (fresh and dry matter) and in shoot and root of wheat plants. Also, the increase of mineral content in shoot as compared with root especially $\mathrm{K}^{+}, \mathrm{Ca}^{++}$and $\mathrm{Mg}^{++}$indicted that $\mathrm{Cu}^{++}$increase wheat efficiency to translocate these minerals from root to shoot which functioning in their share in osmotic adjustment of the cell sap resulted an increase in water content especially at lower and moderate $\mathrm{Cu}^{++}$concentrations. This reflected also on the tolerant of shoot organ than root to the $\mathrm{Cu}^{++}$toxicity. Genotypical differences in tolerance to copper are well known in certain species and ecotypes of natural vegetation [22] [23].

Azospirillum inoculation exhibited a promotion in the accumulation of soluble sugar and soluble protein, which concomitant with the increase in OP. Finally, this activation reflected on the production of fresh and dry matter of the tested plants under $\mathrm{Cu}^{++}$treatment. It can be observed from the data that shoot response higher than root to the Azospirillum inoculation which reflected the interaction effect of the two fertilizers $\mathrm{Cu}^{++}$and Azospirillum application. Thus, Azospirillum and $\mathrm{Cu}^{++}$counteracted to enhancement wheat plant growth and the higher activated effect was observed at low cupper concentration $(5 \mathrm{mM}$ $\mathrm{Cu}^{++}$). The ability to form plant hormones is a property of microorganisms and PGPB, Azospirillum species stimulate and facilitate plant growth [24] [25]. Azospirillum spp. has ability to produce plant hormones, polyamines and amino acids in culture media [26]. Among these hormones, indoles, mainly indole-3acetic acid IAA [27], and gibberellins (GA3) of several kinds [28] may play a significant role. Nitrogen fixation was considered as a major mechanism by which Azospirillum enhanced plant growth [28] [29]. Also, a possible strategy for improvement plant is a lowering of metal toxicity in contaminated soils which inhibited plant growth. Although, the bacterium tolerate only moderate concentrations of metals and many toxic compounds [30]. The present data 
showed that relative nutrient content increased with increasing $\mathrm{Cu}^{++}$content until reach a higher values at $25 \mathrm{mM} \mathrm{Cu}^{++}$concentration with Azospirillum application. Inoculation facilitated in the plant yield and mineral content by some selected mechanisms or by a cascade of mechanisms operating simultaneously under suitable conditions [31] [17] [32]. Finally, wheat plants response differentially to $\mathrm{Cu}^{++}$treatment according to its organ and Azospirillum brasilense treatment increased wheat plant efficiency to tolerate the effect of $\mathrm{Cu}^{++}$stress.

\section{Acknowledgements}

This work was grateful to my Father, Mahmoud Abd El-Samad, my Mother Karema, Kotob, Brother Ahmed, Sisters, Naema and Fatma and all other members of my family.

\section{References}

[1] Marschner, H. (1995) Mineral Nutrition of Higher Plants. Academic Press, London, 344-346. http://oxfordindex.oup.com/view/10.1006/anbo.1996.0155

[2] Puig, S., Colas, A.N., Garacia, M.A. and Penarrubia, L. (2007) Copper and Iron Homeostasis in Arabidopsis. Response to Metal Deficiencies, Interactions and Biotechnological Applications. Plant, Cell \& Environment, 30, 271-290. http://www.sciencedirect.com/science/book/9780124735422 https://doi.org/10.1111/j.1365-3040.2007.01642.x

[3] Hamdia, M.A. and El-Komy, H.M. (1997) Effect of Salinity, Gibberellic Acid and Azospirillum Inoculation on Growth and Nitrogen Uptake of Zea mays. Biologia Plantarum, 40, 109-120. http://link.springer.com/article/10.1023/A:1000904819841 https://doi.org/10.1023/A:1000904819841

[4] Hamdia, A.B.E., Shaddad, M.A.K. and Doaa, M.M. (2004) Mechanisms of Salt Tolerance and Interactive Effects of Azospirillum brasilense Inoculation on Maize Cultivars Grown under Salt Stress Conditions. Plant Growth Regulation, 44, 165-174. http://mu.minia.edu.eg/publications/administrator/components/com_jresearch/file s/publications/Mechanisms\%20of\%20salt\%20tolerance $\% 20$ and $\% 20$ interactive $\% 20 \mathrm{ef}$ fects $\% 20$ of $\% 20$ Azospirillum $\% 20$ brasilense $\% 20$ inoculation $\% 20$ on $\% 20$ maize $\% 20$ culti vars\%20grown $\% 20$ under\%20salt\%20stress\%20conditions.pdf https://doi.org/10.1023/B:GROW.0000049414.03099.9b

[5] Tejera, N.C., Lluch, M.V., Martìnez-Toledo, V. and Gonzàlez-López, J. (2005) Isolation and Characterization of Azotobacter and Azospirillum Strains from the Sugarcane Rhizosphere. Plant and Soil, 270, 223-232. http://link.springer.com/article/10.1007\%2Fs11104-004-1522-7

[6] Bashan, Y., Puente, E., Rodriguez-Mendonza, N.N., Holguin, G., Toledo, G., Cerrato, F. and Pedrin, S. (1995) Soil Parameters Which Effect the Survival of Azospirillum brazilense. In: Fendrik, C., Del Callo, M., Vanderleden, J. and Zamaroczy, M., Eds., Azospirillum and Related Microorganisms, Springer Verlag, Germany, 441450. http://link.springer.com/book/10.1007\%2F978-3-642-79906-8?page=3

[7] Romero, A.M., Correa, O.S., Moccia, S. and Rivas, J.G. (2003) Effect of Azospirillum-Mediated Plant Growth Promotion on the Development of Bacterial Diseases on Fresh-Market and Cherry Tomato. Journal of Applied Microbiology, 95, 832838. https://www.ncbi.nlm.nih.gov/pubmed/12969298 https://doi.org/10.1046/j.1365-2672.2003.02053.x

[8] Sangeeth, K.P., Suseela Bhai, R. and Srinivasan, V. (2008) Evaluation of Indigenous 
Azospirillum Isolates for Growth Promotion in Black Pepper (Piper nigrum L.) Rooted cuttings. Journal of Spices and Aromatic Crops, 17, 128-133.

http://www.indianspicesociety.in/josac/index.php/josac/article/view/39

[9] Tibbits, T.W. and Langhans, R.W. (1993) Controlled-Environment Studies. In: Hall, D.O., Scur, R.W., Lock, J.M., Bolhar-Nordenkampf, H.R., Leegoood, R.C. and Long, S.P., Eds., Photosynthesis and Production in a Changing Environment, Chapman \& Hall, London, 65-78.

http://link.springer.com/chapter/10.1007/978-94-011-1566-7_5

[10] El-Komy, H.M. (992) Ecological and Physiological Studies on the Genus Azospirillum from the Rhizospere of Maize and Rice Plants. PhD Thesis, Institute of Agricultural Microbiology, Russian Acad. Agr. Sci., Sankt Petbeurg.

https://books.google.com.eg/books?id=90DwCAAAQBAJ\&pg=PA50\&lpg=PA50\&d q=El+Komy1992

[11] Fales, F.W. (1951) The Assimilation and Degradation of Carbohydrates of Yeast Cells. Journal of Biological Chemistry, 193, 113-118.

http://www.jbc.org/content/193/1/113.full.pdf

[12] Lowry, O.H., Roserbrough, N.J., Farr, A.L. and Randall, R.J. (1951) Protein Measurement with the Folin Phenol Reagent. Journal of Biological Chemistry, 193, 265 275. http://en.wikipedia.org/wiki/Journal_of_Biological_Chemistry

[13] Williams, V. and Twin, S. (1960) Flam Photometric Methods for Sodium, Potassium and Calcium. In: Paech, K. and Tracey, M.V., Eds., Modern Methods of Plants Analysis, Vol. V, Springer-Verlag, Berlin, 3-5. https://en.wikipedia.org/wiki/The_Williams_Brothers

[14] Schwarzenbach, G. and Biedermann, W. (1948) Komplexone, X. Erdalkalikomplexe von o, o'-Dioxyazofarbstoffen. Helvetica Chimica Acta, 31, 678-687. https://doi.org/10.1002/hlca.19480310303

[15] Steel, R.G. and Torrie, J.H. (1960) Principles and Procedures of Statistics. McGrawHill Book Co., New York. http://garfield.library.upenn.edu/classics1977/A1977DU23500002.pdf

[16] Lai, W.-A., Rekha, P.D., Arun, A.B. and Young, C.-C. (2008) Effect of Mineral Fertilizer, Pig Manure, and Azospirillum rugosum on Growth and Nutrient Contents of Lactuca sativa L. Biology and Fertility of Soils, 45, 155-164.

https://www.researchgate.net/publication/227207112 https://doi.org/10.1007/s00374-008-0313-3

[17] Shelud'ko, A.V., Varshalomidze, O.E., Petrova, L.P. and Katsy, E.I. (2012) Effect of Genomic Rearrangement on Heavy Metal Tolerance in the Plant-Growth-Promoting Rhizobacterium Azospirillum brasilense Sp245. Folia Microbiologica, 57, 5-10. https://www.ncbi.nlm.nih.gov/pubmed/22130692

[18] Hamdia, M.A. (2014) Physiological Strategy Effect of Heavy Metal on Plant Production. Asian Academic Research, 1, 1-25. http://www.asianacademicresearch.org/january2014.html

[19] Yruela, I. (2009) Copper in Plants: Acquisition, Transport and Interactions. Functional Plant Biology, 36, 409-430. https://doi.org/10.1071/FP08288 http://www.publish.csiro.au/FP/FP08288

[20] Yuan, H.M., Xu, H.H., Liu, W.C. and Lu, Y.T. (2013) Copper Regulates Primary Root Elongation through PIN1-Mediated Auxin Redistribution. Plant and Cell Physiology, 54, 766-778. https://www.ncbi.nlm.nih.gov/pubmed/23396597 https://doi.org/10.1093/pcp/pct030

[21] Halliwell, B. and Gutteridge, J.M.C. (1984) Oxygen Toxicity, Oxygen Radicals, Transition Metals and Disease. Biochemical Journal, 219, 1-14. 
https://www.ncbi.nlm.nih.gov/pmc/articles/PMC1153442/ https://doi.org/10.1042/bj2190001

[22] Woolhouse, H.W. (1983) Toxicity and Tolerance in Response of Plants to Metals. In: Lange, O.L., et al., Eds., Encyclopedia of Plant Physiology, New Series, Vol. 12C, Springer-Verlag, Berlin, 245-300. http://www.apis.ac.uk/toxicity-and-tolerance-responses-plants-metals

[23] Blamey, F.P.C., Nishizawa, N.K. and Yoshimura, E. (2004) Timing, Magnitude, and Location of Initial Soluble Aluminium Injuries to Mungbean Roots. Soil Science and Plant Nutrition, 50, 67-76.

http://www.google.co.uk/url?url=http://www.tandfonline.com/doi/pdf/10.1080/ https://doi.org/10.1080/00380768.2004.10408453

[24] Hamdia, M.A. (2005) Improvement of Salt Tolerance by Biofertilizers. Current Topics in Plant Biology, 6, 41-55.

http://cyberleninka.ru/article/n/salt-tolerance-of-crop-plants

[25] Tsavkelova, E.A., Klimova, S.Y., Cherdyntseva, T.A. and Netrusov, A.I. (2006) Microbial Producers of Plant Growth Stimulators and Their Practical Use: A Review. Prikladnaya Biokhimiya i Microbiologiya, 42, 133-143. https://www.ncbi.nlm.nih.gov/pubmed/16761564

[26] Rafi, M.M., Varalakshmi, T. and Charyulu, P.B. (2012) Influence of Azospirillum and PSB Inoculation on Growth and Yield of Foxtail. Journal of Microbiology and Biotechnology Research, 2, 558-565.

http://www.google.co.uk/url?url=http://shodhganga.inflibnet.ac.in/jspui/bitstream/ 10603/137733/12/12_reference.pdf\&rct=j\&frm $=1 \& q=\& e s r c=s \& s a=U \& v e d=0 a h U K E$ wiV8pLX7bLTAhVGVRQKHWtaDKoQFggWMAE\&usg=AFQjCNHEoLcVnjB-lyF WYdJ7sv89ABSUKA

[27] Spaepen, S., Vanderleyden, J. and Remans, R. (2007) Indole-3-Acetic Acid in Microbial and Microorganism-Plant Signaling. FEMS Microbiology Reviews, 31, 425 448. https://www.ncbi.nlm.nih.gov/pubmed/17509086 https://doi.org/10.1111/j.1574-6976.2007.00072.x

[28] Bottini, R., Cassan, F. and Piccoli, P. (2004) Gibberellin Production by Bacteria and Its Involvement in Plant Growth Promotion and Yield Increase. Applied Microbiology and Biotechnology, 65, 497-503.

https://www.ncbi.nlm.nih.gov/pubmed/15378292 https://doi.org/10.1007/s00253-004-1696-1

[29] Kennedy, I.R., Choudhury, A.A. and Kecskes, M.L. (2004) Non-Symbiotic Bacterial Diazotrophs in Crop-Farming Systems: Can Their Potential for Plant Growth Promotion Be Better Exploited? Soil Biology \& Biochemistry, 36, 1229-1244. https://pdfs.semanticscholar.org/4040/50b0b565e1efc34d7ba5adb575871cf39f51.pdf

[30] Bashan, Y. and Bashan, L.E. (2010) How the Plant Growth-Promoting Bacterium Azospirillum Promotes Plant Growth-A Critical Assessment. Advances in Agronomy, 108, 77-136. https://www.researchgate.net/publication/251449020

[31] Steenhoudt, O. and Vanderleyden, J. (2000) Azospirillum Free Living NitrogenFixing Bacterium Closely Associated with Grasses: Genetic, Biochemical and Ecological Aspects. FEMS Microbiology Reviews, 24, 487-506.

https://www.ncbi.nlm.nih.gov/pubmed/10978548 https://doi.org/10.1111/j.1574-6976.2000.tb00552.x

[32] Mantelin, S. and Touraine, B. (2004) Plant Growth-Promoting Bacteria and Nitrate Availability: Impacts on Root Development and Nitrate Uptake. Journal of Experimental Botany, 55, 27-34. https://www.ncbi.nlm.nih.gov/pubmed/14623902 https://doi.org/10.1093/jxb/erh010 


\section{Abbreviations}

$\mathrm{ER}$, endoplasmic reticulum;

IAA, indole-3-acetic acid;

$\mathrm{GA}_{3}$, gibberellins;

$\mathrm{OP}$, osmotic pressure;

Azospirillum, Az.

Submit or recommend next manuscript to SCIRP and we will provide best service for you:

Accepting pre-submission inquiries through Email, Facebook, LinkedIn, Twitter, etc. A wide selection of journals (inclusive of 9 subjects, more than 200 journals) Providing 24-hour high-quality service User-friendly online submission system Fair and swift peer-review system Efficient typesetting and proofreading procedure Display of the result of downloads and visits, as well as the number of cited articles Maximum dissemination of your research work

Submit your manuscript at: http://papersubmission.scirp.org/ Or contact ajps@scirp.org 